\title{
IAMJ
}

INTERNATIONAL

AYURVEDIC

MEDICAL JOURNAL

ISSN: 2320-5091

Impact Factor: 6.719

\section{PHARMACEUTICAL STANDARDIZATION OF AGNIKUMARA RAS}

\author{
Archana Sripada ${ }^{1}$, G. Ramesh Babu. ${ }^{2}$, V. Badari Narayana ${ }^{3}$, Ch. Sri Durga ${ }^{4}$ \\ ${ }^{1}$ P.G Scholar, ${ }^{2}$ Associate Professor, ${ }^{3}$ P.G Lecturer, ${ }^{4}$ Professor \& HOD \\ Department of Rasa Shastra and Bhaishajya Kalpana, S.V Ayurveda College, TTD, Tirupati, \\ Andhra Pradesh, India
}

Corresponding Author: sripadagold@gmail.com

\section{https://doi.org/10.46607/iamj0809112021}

(Published Online: November 2021)

Open Access

(C) International Ayurvedic Medical Journal, India

Article Received: 18/10//2021 - Peer Reviewed: 10/11/2021 - Accepted for Publication: 13/11/2021

\section{Check for updates}

\begin{abstract}
Bhaishajya Kalpana is an integral part of Ayurveda which deals with the process of preparation of single and compound formulations. The preparation of drugs can be classified into two groups, primary and secondary. Vati is a popular secondary preparation in Ayurvedic pharmaceutics. It is a solid dosage form that is produced and marketed in the field of pharmaceutics. This is because of the advantages like it can be swallowed easily without any irritation, handy and fixation of dosage becomes easier. Agnikumara Ras is one such formulation mentioned in Basavarajeeyam pradhama prakarana indicated in Peenasa, Jwara, ama and Pratishyaya. Agnikumara ras contains Shuddha Vatsanabha, Maricha, Mustha, Kushta and Vacha. The pharmaceutical procedures adopted in this study are Shodana, Churna nirmana, mardana and preparation of vati of Agnikumara ras. Till now, no research work has been carried out to standardize the method of preparation Agnikumara Ras. Therefore, the present study has been planned to standardize the method of preparation of Agnikumara ras according to the method explained in the classics.
\end{abstract}

Keywords: Agnikumara ras, Shodana, Churna nirmana, pharmaceutical standardization.

\section{INTRODUCTION}

The pharmaceutical study is the study of drug manufacturing. Rasa Shastra and Bhaishajya Kalpana is the pharmaceutical branch of Ayurveda. It is a well-established branch serving humans with its unique heritage 
of drugs derived from minerals, metals and animal origin processed with herbs. In treating an ailment, one of the important steps in preparation of the drug. Most of the drugs as such are not easily absorbable to the biological system, so to make them absorbable and to bring therapeutic effect, some modifications are required through the specialized techniques called the pharmaceutical process. By adopting specialized pharmaceutical procedures like Shodana, Marana, Jarana, Murchana, etc they are converted into non-toxic, safe and potent therapeutic forms.

Though several types of kalpa are being used presently, a Vati plays an important role in Ayurvedic pharmaceutics owing to many advantages like easy administration, palatability, convenient form for dispensing and transportation. Hence the present study is planned to prepare the selected drug following all the methods mentioned in classical texts.

Agnikumara ras is a preparation mentioned in Basavarajeeyam Prathama prakarana ${ }^{[1]}$ and indicated in pratishyaya, peenasa, jwara, ama. Agnikumara Ras contains Vatsanabha (Aconitum ferox wall), Maricha (Piper longum Linn), Kushta (Saussurea lappa C.B Clarke), Vacha (Acorus calamus Linn.) and Mustha (Cyperus rotundus Linn). Shodana, Churna nirmana and preparation of Vati are the main pharmaceutical procedures adopted in the preparation of Agnikumara ras. Standardization of Ayurvedic drugs at various levels starting from the selection and collection of raw material to the final product is essential to produce a safe and efficacious drug. Therefore, in the present study, an effort has been made to highlight the significance of these pharmaceutical procedures and to standardize the method of preparation of Agnikumara ras.

\section{Aim and Objectives}

Pharmaceutical standardization of various steps involved in the preparation of Agnikumara Ras.

\section{Materials and Methods}

Chief reference: Basavarajeeyam, Prathama prakarana- Sloka No. 520-525

The entire preparation of Agnikumrara Ras was carried out in the Department of Rasa Shastra and
Bhaishyya Kalpana, S.V Ayurveda College, TTD, Tirupati, Andhra Pradesh.

The entire pharmaceutical study was carried out in four stages:

Stage-I

- Vatsanabha Shodana

\section{Stage II}

- Preparation of Vatsanabha Churna

- Preparation of Maricha Churna

- Preparation of Mustha Churna

- Preparation of Kushta Churna

- Preparation of Vacha Churna

Stage III

- Preparation of Homogeneous mixture

\section{Stage IV}

- Mardana of Homogeneous mixture with Ardraka Swarasa

- Preparation of Vati of Agnikumara Ras.

Agnikumara Ras preparation

- Materials:

Shuddha Vatsanbha-100g

Mustha Churna-25g

Maricha Churna-25g

Vacha Churna-25g

Kushta Churna-25g

Ardraka Swarasa- Q.S

- Method/ Principle: Shodhana, Churna Nirmana, Mardana

- Apparatus: Khalwayantra, Steel vessel, Cloth, Spoon, tray and steel cutter.

Procedure: Shodhana of Vatsanbha was carried out by taking Vatsanbha roots and cut into small pieces i.e., Chanakamatra (size of Bengal gram). The pieces of Vatsanabha were taken in an earthen vessel. Gomutra was poured into it so that the pieces of Vatsanabha get completely immersed in Gomutra. The vessel was kept in sunlight. The next day morning pieces of Vatsanabha were taken out and were placed in another earthen vessel. Fresh Gomutra was added to these pieces. The procedure was repeated three times. The Vatsanabha pieces were taken out and washed properly with hot water and dried. Dried Vatsanabha pieces were taken in a Khalwayantra and pounded to 
make a fine powder. Churna Nirmana of Mustha, Maricha, Kushta and Vacha was carried out by pounding in Khalwayantra and filtered through a cloth to get a fine powder. After that Shuddha Vatsanabha Churna, and Churna of other drugs are mixed until to form a homogenous mixture. A homogenous mixture was taken in Khalwayantra and Ardraka Swarasa was added and triturated. Trituration was done until it attains Vati lakshana. Paste of homogenous mixture was made into $125 \mathrm{mg}$ Vati by rolling the mixture between thumb and index finger. Vati was dried under shade and stored in a glass container.

\section{Observations:}

- During Shodhana of Vatsanbha, the colour of Gomutra changed into dark brown. Shuddha Vatsanabha became brittle and pale.

- After mixing of Churna of all the ingredients a brown coloured homogenous mixture was obtained.

- After Mardana the final product was smooth, light brown. The paste was unsticky when rolled between thumb and index finger. Light, brown-coloured small pills were prepared.

\section{Images}
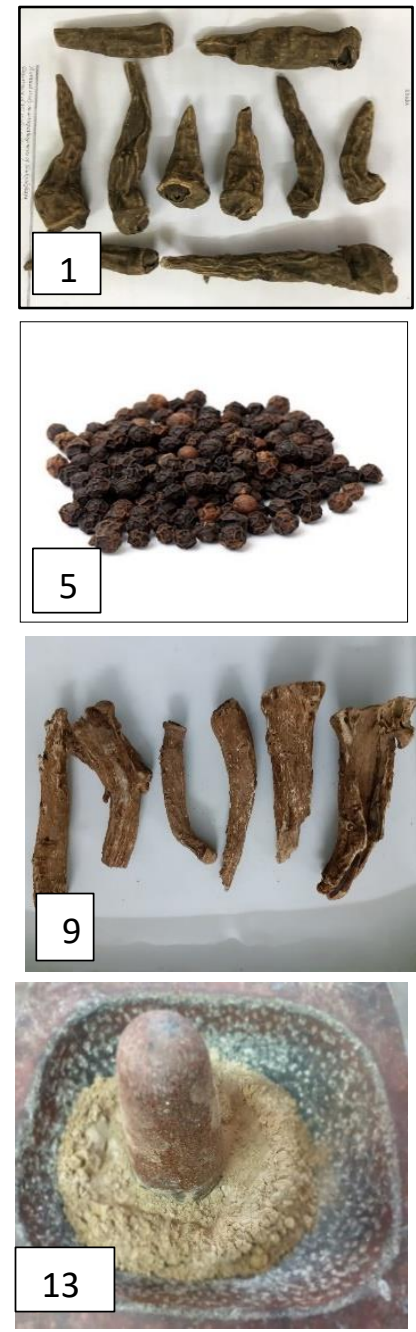

10

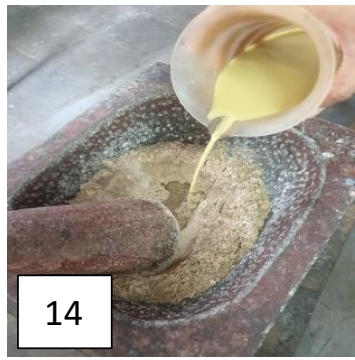

1-Ashuddha Vatsanabha

2-Ashuddha Vatsanabha soaked in Gomutra

3-Shuddha Vatsanabha after drying

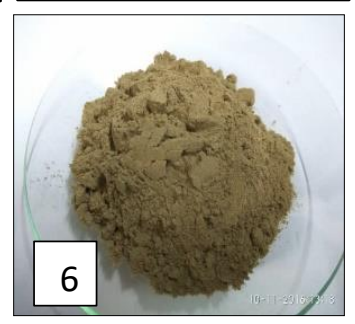

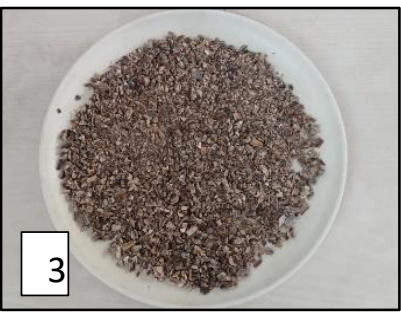
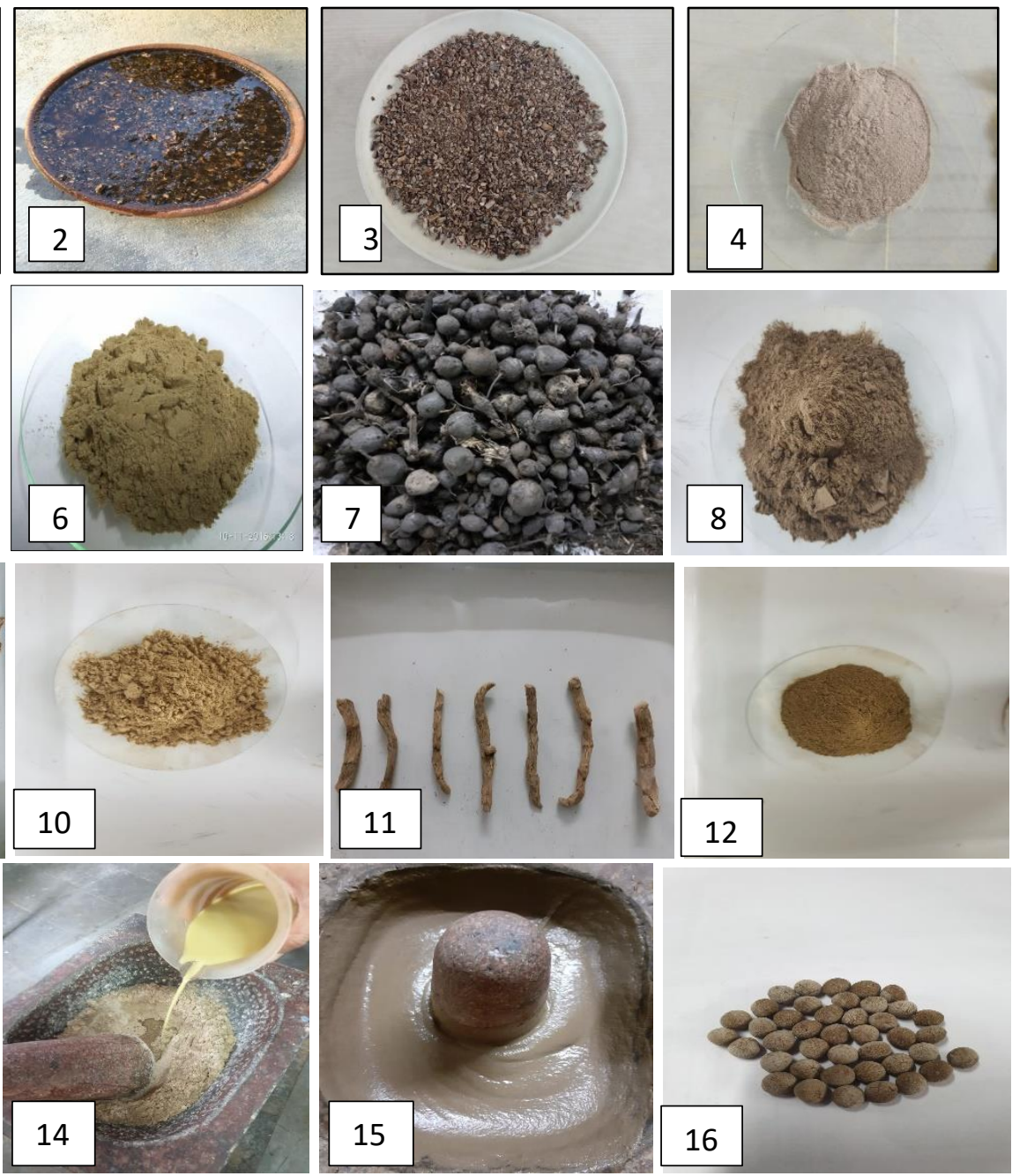

4-Shoditha Vatsanabha Churna

5-Maricha

6-Maricha Churna 


\section{7-Mustha}

8-Mustha Churna

9-Kushta

10-Kushta Churna

11-Vacha

12-Vacha Churna

13-Homogeneous mixture

14-Adding Ardraka Swarasa to a homogeneous mixture
15-Mardana of homogeneous mixture with Ardraka Swarasa

16-Vati of Agnikumara Ras

\section{Precautions:}

- Trituration should be carried out slow and steady to prevent spillage of the material.

- Pills are to be preserved in an absolute sterile and moisture free glass container.

\section{Results:}

Table 1: Showing the change in weight of various methods in the preparation of Agnikumara ras

\begin{tabular}{|l|l|l|l|}
\hline Name of the practical & Initial weight $(\mathrm{g})$ & Final weight $(\mathrm{g})$ & Gain/loss in weight (g) \\
\hline 1. Vatsanabha Shodana & $100 \mathrm{~g}$ & $80 \mathrm{~g}$ & $20 \mathrm{~g}$ \\
\hline 2. Maricha Churna & $25 \mathrm{~g}$ & $20 \mathrm{~g}$ & $5 \mathrm{~g}$ \\
\hline 3. Mustha Churna & $25 \mathrm{~g}$ & $20 \mathrm{~g}$ & $5 \mathrm{~g}$ \\
\hline 5. Kushta Churna & $25 \mathrm{~g}$ & $20 \mathrm{~g}$ & $5 \mathrm{~g}$ \\
\hline
\end{tabular}

Table 2: Showing the result of mixing of component drugs of Agnikumara ras

\begin{tabular}{|l|l|l|l}
\hline Initial weight & Final weight & Loss in weight & Loss in percentage \\
\hline $160 \mathrm{~g}$ & $150 \mathrm{~g}$ & $10 \mathrm{~g}$ & $6.25 \%$
\end{tabular}

Table 3: Showing the results of preparation of Vati of Agnikumara ras

\begin{tabular}{|l|l|l|}
\hline Weight of Agnikumara Ras & No. of Vati (each of $125 \mathrm{mg}$ ) & Loss \\
\hline $150 \mathrm{~g}$ & 1180 & $3 \mathrm{~g}$ \\
\hline
\end{tabular}

\section{DISCUSSION}

The use of metals and some poisonous herbal drugs in medicine is often associated with toxicity, but Ayurveda made them into biocompatible form by certain detoxification processes like Shodana, Marana, Bhavana etc. which remove the toxic potential from minerals and imparts them with therapeutic efficacy of a high-grade.

\section{Vatsanabha Shodhana}

Vatsanabha without Shodhana if administered may cause Murcha (syncope), Hrut Gatirodana (cardiac arrest) which may lead to Mrutyu (death), so purification of Vatsanabha is necessary before administration. ${ }^{[2]}$ According to Rasa Tarangini, Shodhana of Vatsanabha was done by submerging Vatsanabha pieces in Gomutra and exposing them to Sunlight for 3 days. ${ }^{[3]}$ Asuddha Vatsanabha contains 0.4- 0.8\% diterpene alkaloids and the concentration of aconite is between $0.3-2.0 \%$. The major alkaloids are aconitine, pseudoaconitine, diacetyl-pseudo aconitine, aconine etc. ${ }^{[4]}$ After Shodhana process, the total alkaloids content decreases, ${ }^{[5]}$ but the concentration of a less toxic substance such as aconine, hypoaconine and benzylhypoaconine increases ${ }^{[6,7]}$ possibly due to conversion of toxic aconitine into aconine or hydrolysis of alkaloids to their respective amino alcohols after Shodhana. ${ }^{[8,9]}$ Gomutra converts aconite to a compound with cardiac stimulant property, whereas raw aconite shows a cardiac depressant property. ${ }^{[10-13]}$ Vatsanabha treated by cow's urine on TLC studies have shown that pseudoaconitine and aconitine were converted into far less toxic substances veratroyl pseudoaconine and benzoylaconine respectively only in traditional Ayurvedic Shodhana. ${ }^{[14]}$ After Shodhana Gomutra became dark in colour, as the toxic substances from Vatsanabha were dissolved in it. A study had revealed that 
administration of raw aconite leads to impairment in kidney and liver functions and administration of aconite treated in cow's milk leads to toxicity in the kidney, but administration of aconite treated in cow's urine reduces the toxic effect of aconite significantly. ${ }^{[15]}$

\section{Churna nirmana of herbal drugs:}

Maricha, Mustha, Vacha and Kushta were made into a fine powder, according to the reference mentioned in Sharangadhara Samhita Madhyama Khanda. ${ }^{[16]}$

Preparation of a homogenous mixture of all component drugs:

Vatsanabha was obtained after Shodhana, and the fine powders of herbal drugs were mixed in the ratio as mentioned in the reference Sloka to obtain the homogenous mixture of Agnikumara Ras. ${ }^{[17]}$

Mardana of Homogenous mixture with Ardraka Swarasa

The homogenous mixture was taken in Khalwayantra and Ardraka swarasa was added and triturated until it attains Vatilakshanas. ${ }^{[18]}$ By the Mardana process, the mixture gets properly mixed, and the material becomes soft, smooth and unsticky. Mardana facilitates particle size reduction and homogenization leading to modification of properties (Gunantatradhana) of the product.

\section{Preparation of Agnikumara Ras Vati:}

According to Basavarajeeyam dosage of Agnikumra Ras is 1 Ratti (125mg). ${ }^{[19]}$ Mardita Homogenous mixture of $125 \mathrm{mg}$ was taken and rolled between thumb and index finger.

\section{CONCLUSION}

Pharmaceutical standardization of various formulations is an important requisite for the establishment of their efficacy and consistent biological activity. The pharmaceutical procedures involved in this study are Shodhana, Churna Nirmana, Mardana and preparation of Vati of Agnikumara ras. Shodhana plays a vital role by removing the toxic nature and improving the therapeutic efficacy, thereby rendering a safe and effective formulation. There is a quote mentioned as "mardanam guna vardanam" which means the more mardana(grinding) is done the more guna(property) will imbibe in the drug. The process of grinding reduces the particle size that in turn will increase the surface area of the drug.

\section{REFERENCES}

1. Vaidya Shree Basavaraja, Basavarajeeyam, Chapter 1/520-525, Choukambha, Varanasi.2014, Page No. 53

2. Pandita Kashinath Shastri. Rasa Tarangini by Pranacharya Sri Sadananda Sharma, chapter 24/18, Mothilal Banarasi Das, 2014, Page No. 651

3. Pandita Kashinath Shastri. Rasa Tarangini by Pranacharya Sri Sadananda Sharma, chapter 24/19-22, Mothilal Banarasi Das, 2014, Page No. 651

4. Amalajyothi, Aruna Naga et al. Vatsanabha: An Agada Perspective; International Ayurvedic Medical Journal (IAMJ), (2016 July), 1235-41p.

5. Sarkar PK, Prajapati PK, Shukla VJ, Ravishankar B. Evaluation of the effect of Shodana process on pharmacological activities of aconite. Indian J Pharm Educ Res (2012); 46;243-247p.

6. Singh LB. Poisonous (Visa) plants in Ayurveda $2^{\text {nd }}$ ed. Varanasi; Chaukamba Sanskrit bhawan; 2003

7. Deore SL, Moon KV, Khadabadi SS, Deokate UA, Baviskar BA. Evaluation of toxicity of Vatsanabha (Aconitum Ferox, renunculaceae) before and after Shodana. J Young Pharm (2013): 5: 3-6p.

8. Handa KL, Chopra IC, Kohli JD, Singh K. Mitigation of aconite; a Preliminary note. Indian J Med Res 1951; 39: 89-98p.

9. Parikh KM, Doshi VJ, Salukhe UB, Dhanvate AA. Authentication of detoxification process used in traditional Indian medicine. Inthortic Soc Acta Hortic 1996; 426:57-4

10. Arstogi S. A review of aconite (Vatsanabha) usage in Ayurvedic formulations; Traditional views and references. Spatula DD 2011; 1:233-44.

11. Singh LB. Poisonous (Visa) plants in Ayurveda $2^{\text {nd }}$ ed. Varanasi; Chaukambha Sanskrit bhawan; 2003.

12. Paul A. Effects of Ayurvedic Shodhana (processing) on dried tuberous Aconite (Aconitum napellus Linn.) root. Indones J Pharm 2013; 24:40-6.

13. Tai YT, But PP, Young K, Lau CP. Cardiotoxicity after accidental herb induced aconite poisoning. Lancet 1992;340: 1254-6p.

14. Deore SL, Moon KV, Khadabadi SS, Deokate UA, Baviskar BA. Evaluation of toxicity of Vatsanabha (Aconitum Ferox, Ranunculaceae) before and after Shodana. J Young Pharm 2013 3:5: 3-6p. 
15. P.K. Sarkar P. K Prajapati V.J. Shukla and B. Ravishankar: Effect of Shodhana Treatment on Chronic toxicity and recovery of Aconite; Toxicology International journal 2012 Jan-Apr; 19(1): 35-41p.

16. Sharangadhara, Sharangadhara Samhita of with the Hindi commentary by Dr. Brahmanand Tripathi, Madhyama Khanda Chapter 6/1, Chaukambha Subharati Prakshan Varanasi. 2011, page No. 172.

17. Vaidya Shree Basavaraja, Basavarajeeyam, Chapter 1/520-525, Choukambha, Varanasi.2014, Page No. 53

18. Vaidya Shree Basavaraja, Basavarajeeyam, Chapter 1/520-525, Choukambha, Varanasi.2014, Page No. 53

19. Vaidya Shree Basavaraja, Basavarajeeyam, Chapter 1/520-525, Choukambha, Varanasi.2014, Page No. 53

\section{Source of Support: Nil Conflict of Interest: None Declared}

How to cite this URL: Archana Sripada et al: Pharmaceutical Standardization Of Agnikumara Ras. International Ayurvedic Medical Journal \{online\} 2021 \{cited November 2021\} Available from: http://www.iamj.in/posts/images/upload/2692_2697.pdf 